\title{
Species of white-tailed forest rats hunted and traded, their conservation status and habitat characteristics, in North Sulawesi, Indonesia
}

\author{
SYLVIA LAATUNG ${ }^{1,2, \boldsymbol{v}}$, ASNATH M. FUAH ${ }^{3}$, BURHANUDDIN MASY'UD ${ }^{4}$, CECE SUMANTRI $^{3}$, SALUNDIK $^{3}$ \\ ${ }^{1}$ Department of Animal Production and Technology, Graduate School, Institut Pertanian Bogor. Jl. Raya Dramaga, Kampus IPB Dramaga, Bogor 16680, \\ West Java, Indonesia \\ ${ }^{2}$ Departement of Animal Husbandry, Universitas Sam Ratulangi. Jl. Kampus Unsrat Kleak-Bahu, Manado 95115, North Sulawesi, Indonesia. \\ "email: sylvia_laatung@apps.ipb.ac.id \\ ${ }^{3}$ Department Animal Production and Technology, Faculty of Animal Science, Institut Pertanian Bogor. Jl. Agatis, Kampus IPB Darmaga, Bogor 16680, \\ West Java, Indonesia \\ ${ }^{4}$ Department of Forest Resources, Conservation and Ecotourism, Faculty of Animal Science, Institut Pertanian Bogor. Jl. Ulin, Kampus IPB Darmaga, \\ Bogor 16680 West Java, Indonesia
}

Manuscript received: 4 March 2021. Revision accepted: 20 June 2021.

\begin{abstract}
Laatung S, Fuah AM, Masy'ud B, Sumantri C, Salundik 2021. Species of white-tailed forest rats hunted and traded, their conservation status and habitat characteristics, in North Sulawesi, Indonesia. Biodiversitas 22: 2778-2784. The tradition of hunting and trading white-tailed forest rats, especially in North Sulawesi, has been practiced for generations. This poses a threat to the existence of these animals in their natural habitat leading to the extinction of some hunted species. In the past, studies on white-tailed rats being hunted and traded on Sulawesi is still lacking. Therefore, the purpose of this study is to identify the species of white-tailed forest rats hunted and traded, their conservation status and habitat characteristics in North Sulawesi. This study was conducted in April to June 2018 in Minahasa and Bolaang Mongondow District, North Sulawesi. The survey methods used involved visiting hunters, recording and taking pictures of the species of rats being hunted and traded. All samples of white-tailed rats were identified in the Zoological Laboratory, Indonesian Institute of Sciences Cibinong Bogor, West Java. Furthermore, ascertaining the general characteristics of the habitat was carried out using a general survey in locations known as distribution areas in North Sulawesi. The identification of 125 individuals consists of 8 species of white-tailed forest rats from 7 genera, which are commonly hunted. They include Rattus xanthurus (Gray, 1867), Bunomy fratrorum (Thomas, 1896), Lenomys meyeri (Jentink, 1879), Paruromys dominator (Thomas, 1921), Echiotrix leucura (Gray, 1879), Taeromys taerae (Sody, 1932), Maxomys hellwaldi (Jentink, 1879) and Maxomys musschenbrooki (Jentink, 1878). Four out of the eight species of white-tailed forest rats are protected species according to the IUCN Redlist. The white-tailed forest rats identified in this study, were caught in secondary forest and plantation, ranging from an altitude of $500-1.500$ meters above sea level. Their main sources of feed include Areca catechu, Piper aduncum, Ficus spp., and Arenga piñnata.
\end{abstract}

Keywords: Bushmeat, conservation, hunting, Minahasa, rat

\section{INTRODUCTION}

The predominant issue in various countries including Indonesia is the excessive exploitation of natural resources (Herdiansyah et al. 2014). This threatens their sustainability, the integrity of ecosystems, and lowers the carrying capacity and extinction of biodiversity (Wu 2013; Vannevel and Goethals 2020). Since the 17th century, an estimated $2.1 \%$ of mammals and $1.3 \%$ of birds have gone extinct, and the pressure on biodiversity is exacerbated by the rapid increase in the human population (Edet et al. 2014; Di Marco et al. 2018; Verma et al. 2020). Furthermore, in order to meet human needs, there has been a transfer of land functions into residential and agricultural areas that indirectly affect the habitat of wild animals living in it (Haddad et al. 2015; Crooks et al. 2017). Habitat destruction is the main cause of mass extinction in the tropics today, and one of the most disturbing species is the rat (Alroy 2017).

Poaching and wildlife trafficking to meet the needs of humans are carried out by people living in the countryside (Pattiselanno and Mentasen 2010; Wyatt et al. 2018).
Therefore, the motivation for hunting and trading wildlife meat varies. Some of them are hunted in order to be used as pets, medicinal sources and consumed to meet the protein requirement of the family (Nasi et al. 2011; Novriyanti et al. 2014; Ripple et al. 2016; Herzegovina et al. 2019; Nukraheni 2019; Mirdat et al. 2019). The rate of hunting needs to be controlled otherwise it could cause a reduced population of wildlife animals (Fulton et al. 2011; Gosselin et al. 2015; Quirós-Fernández 2017; Gray et al. 2018; Garshelis et al. 2020). Furthermore, hunting and collecting forest products has been practiced for a long time (Pattiselanno et al. 2015), and an example includes the inhabitants of North Sulawesi. The white-tailed forest rats are one of the wildlife that is targeted by residents living close to the forest borders. Due to the white color at the end of their tale, the locals call it the "white-tailed forest rat". In addition, the adult rat has a white color on the chest and abdomen. Its body size is large, forages on trees at night and makes nests in the soil during the day. They consume only the shoots of young leaves and fruits of trees in the forest. The local name of this rat varies according to its origin. 
The phenomenon of scarcity and decrease in the population of white-tailed forest rats in North Sulawesi is suspected to have begun. This is partly demonstrated from the information given by the traders in one of the traditional markets in Minahasa (Tomohon Market). It was stated that in recent years, white-tailed forest rats sold in the market were obtained from forests located further away from residential areas. Currently more are obtained from those in the western area of North Sulawesi such as in Bolaang Mongondow district and even Gorontalo. The condition also applies to some other species of wildlife that are often hunted for sale or consumption, such as whitetailed forest rats, snakes, flying foxes, and wild pigs (Laatung et al. 2019), and available for sale in $73 \%$ of the markets and supermarkets in North Sulawesi (Latinne et al. 2019).

Increasing demand for the meats of the white-tailed forest rat has an important and positive meaning relating to the opportunities and prospects as an alternative protein source. High demand and prices, encourage people to increase their rate of hunting. One of the conservation efforts that could be done is to breed them in captive breeding. Therefore, alternative solutions that are appropriate in maintaining the existence of this animal and its possible development, are considered important and need to be urgently carried out.

In the past, the species of white-tailed forest rats hunted and traded in North Sulawesi, and the characteristics of their habitat have not been ascertained. However, the results of this study are expected to complement existing data and be a foundation in preserving the species of whitetailed forest rats hunted to increase their population in nature and develop their utilization sustainably through ex situ captivity. Therefore, the aim of this study is to identify the species of forest rats hunted and traded in North Sulawesi and their conservation status.

\section{MATERIALS AND METHODS}

\section{Study area}

Identification of the species of rats hunted and traded in North Sulawesi, Indonesia began with a pre-survey that was conducted for approximately two weeks. This was carried out to search for information about the presence of white-tailed rat sellers in some traditional markets. Based on the results of the pre-survey, the sampling was carried out in two locations namely Pinabetengan Village, South Minahasa District located at coordinates $01^{\circ} 10 ’ 26.66^{\prime \prime} \mathrm{LU}$ and $124^{\circ} .47^{\prime} 19.49^{\prime \prime}$ LS with an altitude of 740 to 800meters above sea level and Singsingon Village, Bolaang Mongondow District located at coordinates $00^{\circ} 48^{\prime} 16.95^{\prime \prime}$ LU and $124^{\circ} .24 ' 58.15^{\prime \prime}$ with an altitude of 941 meters above sea level (Figure 1). Based on the information from the sellers in some traditional markets, the rats that were mostly sold came from the forests around Minahasa District. Furthermore, some of them were from Bolaang Mongondow District. The time required to conduct the initial survey before sampling was approximately two months, starting from May to June 2018.

\section{Procedures}

A survey method was used in collecting all kinds of hunted white-tailed rats from hunters that were ready for sale in traditional markets. The data collection process was carried out for two weeks at each study site, and the rats were grouped according to their type and local name. Furthermore, all of the species documented here are determined from the examination of the specimen stored in the Zoologicum Bogoriense Museum, Cibinong, Java. General characteristic observations and identification of their habitats and sources were carried out in several locations.

\section{Data analysis}

The type of rat, general characteristics of the habitat, and the sources of food were recorded and pictures were also taken. Furthermore, all the results of the study were analyzed descriptively, and equipped with several photos or images. The conservation status of white-tailed forest rats was analyzed by referring to the list of IUCN Red list 2016.

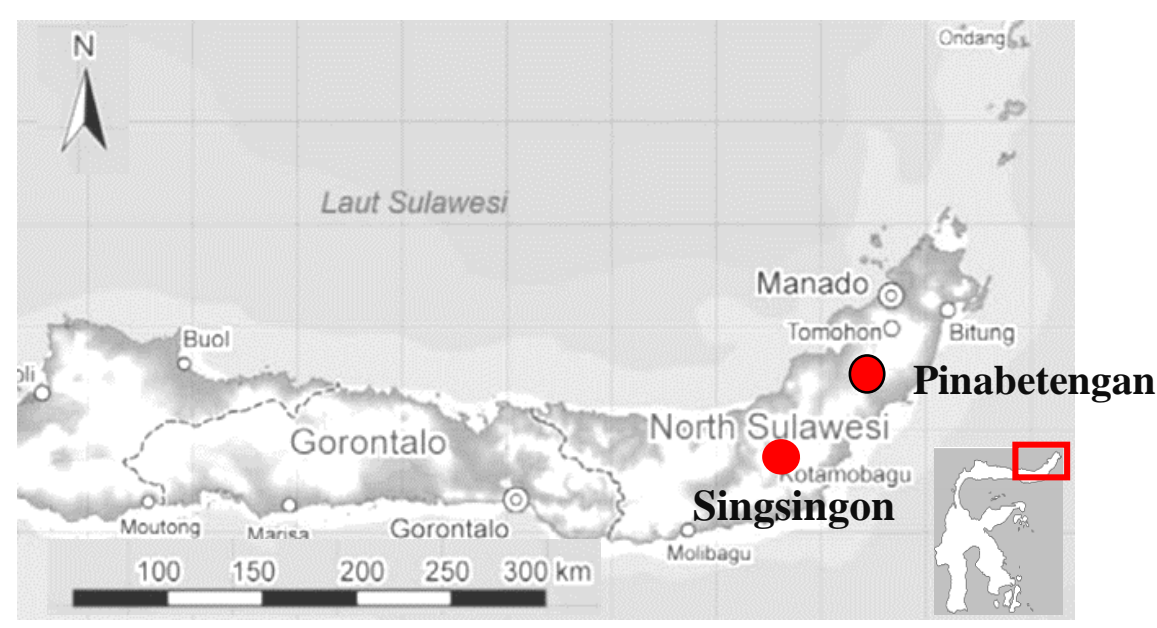

Figure 1. Study sites in Pinabetengan Village, South Minahasa District and Singsingon Village, Bolaang Mongondow District of North Sulawesi Province, Indonesia 


\section{RESULTS AND DISCUSSION}

\section{Species of white-tailed rats hunted and traded}

Based on the results from the two locations, namely Pinabetengan (Minahasa District) and Singsingon Villages (Bolaang Mongondow District), 125 individuals of whitetailed rats were obtained. Eight species of the white-tailed rats, including seven genera, were hunted and traded for consumption in North Sulawesi especially Minahasa, and they all belonged to the family of Muridae (Figure 1). They include Rattus xanthurus (Gray, 1867), Bunomys fratrorum (Thomas, 1896), Lenomys meyeri (Jentink, 1879), Paruromys dominator (Thomas, 1921), Echiothrix leucura (Gray, 1879), Taeromys taerae (Sody, 1932), Maxomys hellwaldi (Jentink, 1979) and Maxomys muschenbroekii (Jentink, 1878). R. xanthurus is only found from northeastern Sulawesi (Musser and Carleton 2005). $B$. fratrorum found in northeast region of the northern peninsula of Sulawesi (Musser and Carleton 2005; Musser 2014). Recent studies have found it also recorded in the western part of the northern peninsula (Handika et al. 2021). L. meyeri is endemic to Sulawesi, found in northern, central, and southwestern (Musser and Carleton 2005). $P$. dominator is widely distributed on Sulawesi from sea level up to the tree-line (Musser and Carleton 2005). E. leucura also endemic to Sulawesi, and found in the northeast tip of the northern peninsula (Musser and Carleton 2005). T. taerae is found in the highlands of northeastern Sulawesi and likely occurs more widely than current records (Musser and Carleton 2005). M. hellwaldi listed as least concern, and spread throughout Sulawesi. M. muschenbroekii is spread throughout Sulawesi, present in several protected areas and adaptable to human disturbance (Musser and Carleton 2005). The species of white-tailed rat, local names, and the number of samples found at each location is presented in Table 1.

Furthermore, the air rifle method was used in catching the animals, however, most hunters in Minahasa use guns to hunt. Several methods and tools are used for hunting rats in Minahasa, but the most widely used is a gun (Laatung et al. 2019). They are considered easy to carry and more practical in their use, especially when hunting for arboreal animals (Wiafe 2018; Cowlishaw and Dunbar 2000). Other methods used are the installation of snares/traps and the use of pet dogs in hunting. Methods used for hunting wildlife depend on many factors such as the behavioral characteristics of hunted animals and hunting habitats (Bakarr et al. 2001; Lone et al. 2015). Bennett and Robinson (2000) define hunting as "all that is captured by humans both mammals, birds, and reptiles, whether dead or alive, regardless of the techniques used to capture hunts".

According to the results of the study by Laatung et al., (2019), the reason for hunting white-tailed forest rats is because hunters take it as a hobby, and the result of the hunt is usually consumed alone or sold for profit. Hunting is also done when there is an order or request for whitetailed forest rats to be presented on special occasions such as family thanksgiving celebrations or other religious events. Some species of rats are hunted because they are pests of plantation habitats, such as the R. xanthurus and L.meyeri species which are both found in coconut plantations. Some studies stated that in addition to consumption and selling to meet the needs of the family, rats are also hunted for damaging and consuming plantation crops. Utilization for consumption purposes has a significant contribution to the availability of animal proteins in rural areas. Furthermore, hunting usually involves members of the family or friends, especially when the location is far from the hunter's house (Laatung et al. 2019). An example of a factor that affects a large number of hunting members is relatively new hunting areas. It requires more hunters, and more methods of hunting (digging traps/holes).

The white-tailed forest rats obtained from the forest were all in a state of death. Furthermore, the ones that had been cleaned and burned, was kept in a plastic basket and taken to a nearby market. Before they are taken to the market, neighbors or villagers who want to buy usually go directly to the hunter's house in the morning and are free to choose the rats they want at a lower price than in the market. Some hunters act as sellers, and market their hunting results in several nearby traditional markets. The white-tailed rats that are sold are generally arranged in such a way based on their type and size. Furthermore, some sell by going around the market carrying baskets or plastic trays containing some rats, there are also renting certain places inside the market. The price of a white-tailed rat varies depending on its size. For small sizes, Turean weighing $\pm 150 \mathrm{gr}$, are sold at a price of Rp.15.000 to 20.000 /individuals. Medium size is $( \pm 200 \mathrm{gr})$ sold for Rp.25.000/individuals, and the largest size (> 200gr) sold at a price of Rp. 27.000 to $35.000 /$ individuals. Some sellers sell rats for Rp. 100,000 for 3 large rats. Special religious holidays such as Christmas, Easter, or welcoming the new year and thanksgiving for the harvest, the price of rats and other wildlife meat, would be a little more expensive, especially for large rats, sold at a price of $\mathrm{Rp}$. 35.000 to 40.000 / individuals. Hunters also hunt and trade some wildlife in traditional markets in North Sulawesi such as flying foxes, snakes, birds, and wild pigs. Several studies on tropical areas stated that poaching in tropical rainforest areas is unsustainable. Therefore, wildlife resources in these forest areas are particularly vulnerable to overexploitation and would become extinct (Ripple et al. 2016; Harrison et al. 2016; Tilker et al.2018). The tradition of hunting white-tailed forest rats has been going on for generations with a high enough intensity. High hunting activity can lead to a reduction in the population of whitetailed forest rats. It is necessary to think about conservation efforts involving the government and other related NGOs (Non-Governmental Organizations), especially local people around the forest, regarding procedures to protect, conserve, and the possibility of breeding efforts. These efforts expected to be the right solution to ensure the sustainable use of white-tailed forest rats. 
Table 1. Species and composition of white-tailed forest rats hunted and trade in Pinabetengan and Singsingon of North Sulawesi, Indonesia

\begin{tabular}{|c|c|c|c|c|}
\hline Species & Local name & $\begin{array}{c}\text { Pinabetengan, } \\
\text { Minahasa (n) }\end{array}$ & $\begin{array}{c}\text { Singsingon, } \\
\text { B.Mongondow (n) }\end{array}$ & Total \\
\hline Rattus xanthurus (Gray, 1867) & Turean & 15 & 16 & 31 \\
\hline Bunomys fratrorum (Thomas,1896) & Pangusan, Emut, Talingkoy, To'tol & 11 & 9 & 20 \\
\hline Lenomys meyeri (Jentink,1879) & Tangkara, Tangkomot, Tangkilis, Kumekeles & 10 & 6 & 16 \\
\hline Paruromys dominator (Thomas, 1921) & Pangaladen & 7 & 5 & 12 \\
\hline Echiothrix leucura (Gray, 1879) & Tarem, Tadem & 4 & 4 & 8 \\
\hline Taeromys taerae (Sody, 1932) & Sambet & 9 & 8 & 17 \\
\hline Maxomys hellwaldi (Jentink, 1979) & Rentei & 4 & 5 & 9 \\
\hline M. muschenbroekii (Jentink, 1878) & Kalendang, Rarampersen & 5 & 7 & 12 \\
\hline Total & & 65 & 60 & 125 \\
\hline
\end{tabular}

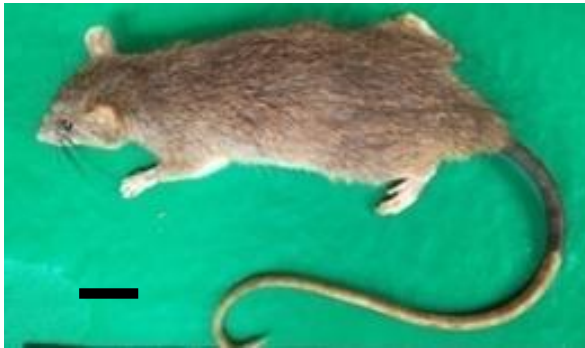

$\mathbf{A}$

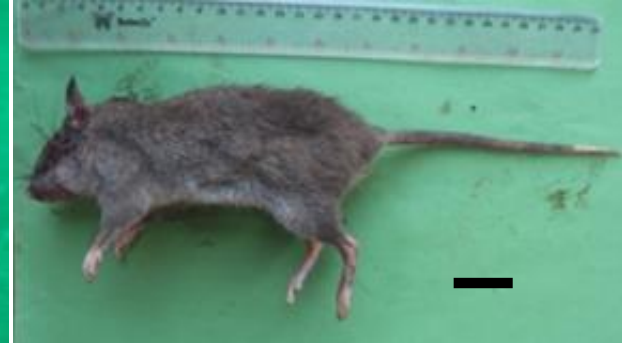

B

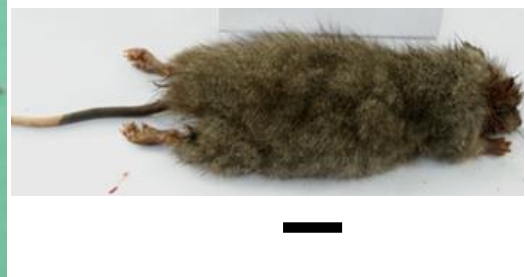

C

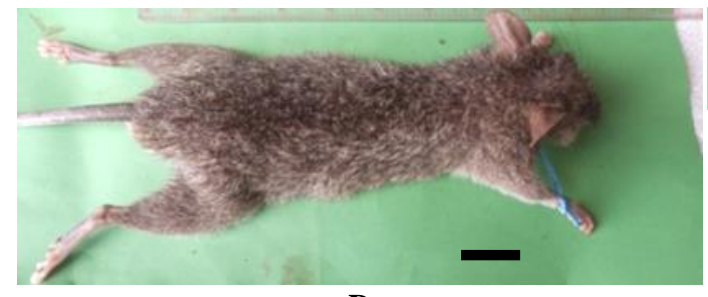

D

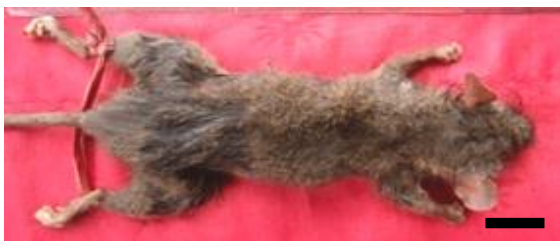

$\mathbf{F}$

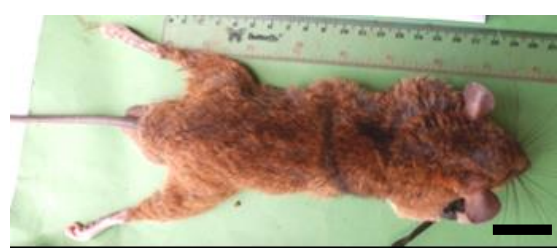

G

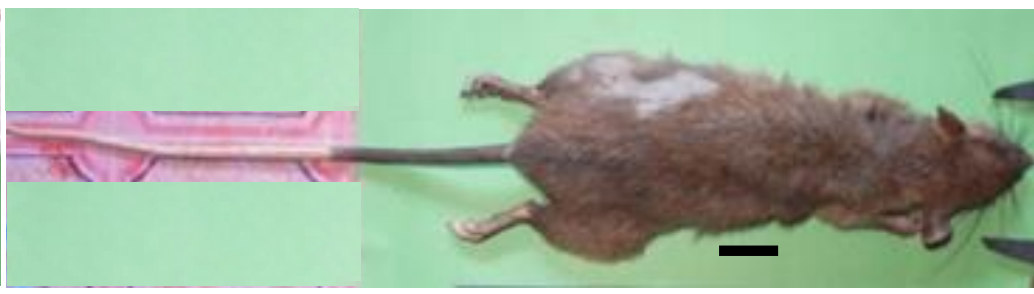

$\mathbf{E}$

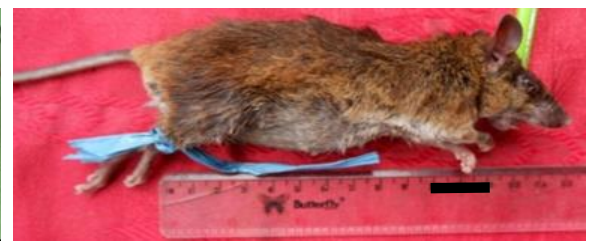

H

Figure 2. Species of white-tailed forest rats hunted and trade. A. Rattus xanthurus, B. Bunomys fratrorum, C. Lenomys meyeri, D. Echiothrix leucura, E. Paruromys dominator, F. Taeromys taera, G. Maxomys hellwaldi, H. M. Muschenbroekii. Bar $=3 \mathrm{~cm}$

\section{Conservation status}

The population trends and conservation status of the eight species of rats outlined above according to the International Union for Conservation of Nature (IUCN) can be seen in Table 2 .

According to the IUCN Red list, four species of rats are almost threatened and vulnerable, namely Rattus xanthurus, Bunomys fratrorum, Taeromys taerae, and Echiothrix leucura. The other four species are categorized as least concerned or mean low risk. The population trend for most of the identified species of rat decreases, and the biggest threats to their population are disturbed habitats such as illegal logging, the conversion of forests into farmland or plantations, and hunting that lasts from year to year for either consumption or sale.
Table 2. Conservation status of the rats according to IUCN Red list 2016

\begin{tabular}{lll}
\hline \multicolumn{1}{c}{ Species } & $\begin{array}{c}\text { Population } \\
\text { trends }\end{array}$ & Conservation status \\
\hline Rattus xanthurus & Decreased & Near threatened \\
Bunomys fratrorum & Decreased & Vulnerable \\
Lenomys meyeri & Decreased & Least concern \\
Paruromys dominator & Stable & Least concern \\
Echiothrix leucura & Decreased & Endangered \\
Taeromys taerae & Unknown & Vulnerable \\
Maxomys hellwaldi & Decreased & Least concern \\
M. muschenbroekii & Stable & Least concern \\
\hline
\end{tabular}

Note: ${ }^{1}$ The IUCN Red List 2016 


\section{Habitat}

One of the components of their habitat that important is the nesting place which is very easy to recognize by experienced hunters. Furthermore, the white-tailed rat usually nests under trees or in the ground, and according to the description of the hunters, the hole where they nests could be recognized from the soil around the hole. Whenever the soil forms large clumps, it is most likely occupied by white-tailed rats. However, when the surrounding soil is small, it is most likely that a blacktailed rat lodges the hole. Some trees that are often used as nesting and sheltering places (Figure 3) are the bamboo trees and wooden flowers/boats (Spathodea campanulata). Temperature and humidity of the air are one of the components of abiotic factors that are important for all living things. The average temperature in Pinabetengan is $26.25^{\circ} \mathrm{C}$ with a high and low of $32.20^{\circ} \mathrm{C}$ and $21.65^{\circ} \mathrm{C}$. While in Singsingon, the average temperature is $26.30^{\circ} \mathrm{C}$ with a high and low of $32.45^{\circ} \mathrm{C}$ and $2.20^{\circ} \mathrm{C}$. In addition, the average relative humidity in Pinabetengan and Singsingon is $85.94 \%$ and $86.65 \%$.

The white-tailed forest rats identified in this study, were caught in secondary forest and plantation, ranging from an altitude of $500-1.500$ meters above sea level. Secondary forest is formed after the clearing of natural forest for livestock and agricultural activities. Secondary forest dominated by some trees like rattan (Calamus spp.), palm trees (Family Arecaceae), Ficus spp. and bamboo. Furthermore, coconut is one of the plantation plants that favor them. This plantation land was located in both research sites, making it a potential source of feed. According to the annual report 2019, the plantation land is about $99.60 \%$ in Minahasa and $60.31 \%$ in Bolaang Mongondow. The presence of rats in these habitats has been a major issue for farmers because it is considered as a pest. Some study also states that rats are also a pest on other plantation crops such as oil palm (Tipawan and Jarun 2016; Ikhsan 2020). According to the information received from hunters and residents around the research site, they also like some fruits such as papaya, bananas, corn, potatoes, and sweet potatoes. Other sources are leaves and nuts, for example, Areca catechu, Piper aduncum, Ficus spp, and Arenga piñnata (Figure 2). Rats are also like young bamboo leaves, bark, tree roots, and young leaf in the forest.

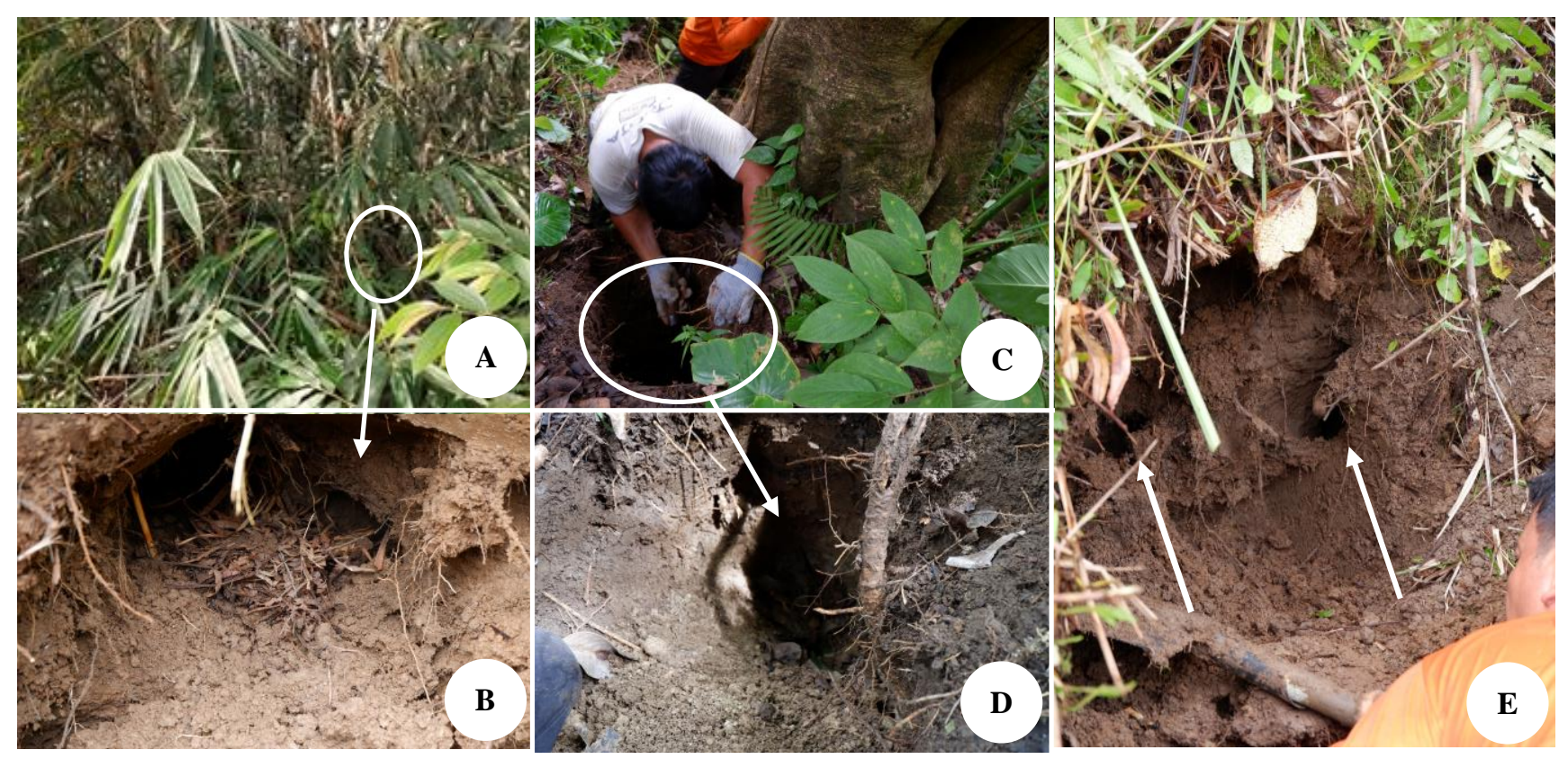

Figure 3. A-B. Nest under the bamboo trees; C-D. Nest under the trees (Spathodea campanulate); E. Two-hole nests

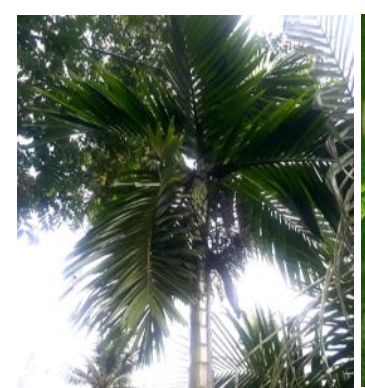

A

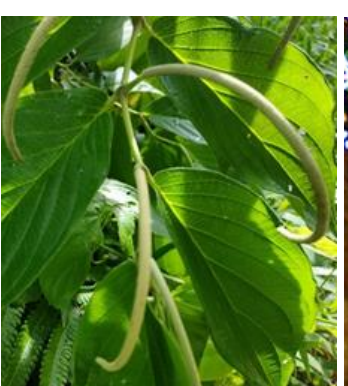

B

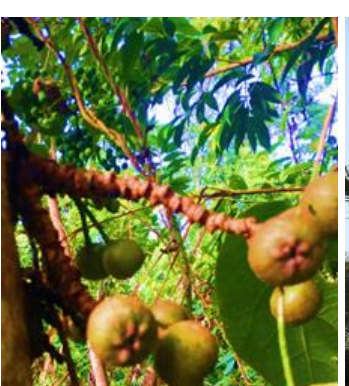

C

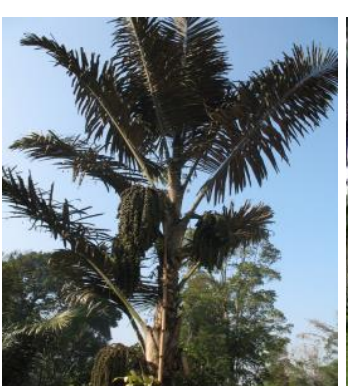

D

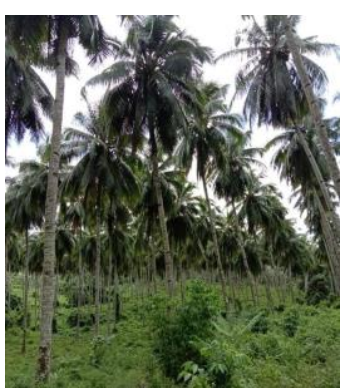

$\mathbf{E}$

Figure 2. Food sources of white-tailed forest rats in North Sulawesi, Indonesia. A. Areca catechu, B. Piper aduncum, C. Ficus spp., D. Arenga piñnata, E. Cocos nucifera 
The harvest of wild meat (bushmeat) by subsistence hunters in tropical countries has resulted in high population decline and extinction on a global-local scale in some bird and mammal species (Bakarr et al. 2001; Cawthorn and Hoffman 2015; Crooks et al. 2017; Di Marco et al. 2018). Forest resources play a significant role for many people that live in or near the forest. These include remote peoples who depend on wildlife for subsistence, source of food, medicine and cultural practices. Good cooperation between local governments, ecologists, conservationists by involving local communities must be done to find the best solution.

In conclusion, the species of white-tailed forest rats hunted and traded were Rattus xanthurus (Gray, 1867), Bunomys fratrorum (Thomas, 1896), Lenomys meyeri (Jentink, 1879), Paruromys dominator (Thomas, 1921), Echiothrix leucura (Gray, 1879), Taeromys taerae (Sody, 1932), Maxomys hellwaldi (Jentink, 1979) and Maxomys muschenbroekii (Jentink, 1878). Furthermore, according to IUCN Red list, there are four species of rats categorized as near threatened (Rattus xanthurus), vulnerable (Bunomys fratrorum and Taeromys taerae) and endangered (Echiothrix leucura). Therefore, it is necessary to pay attention to the conservation efforts of the population. In general, hunted white-tailed forest rats secondary and plantation habitats, and the main sources of feed include Areca catechu, Piper aduncum, Ficus spp and Arenga piñnata.

\section{ACKNOWLEDGEMENTS}

This research did not receive any grant, and the identification of the rats was carried out in the Zoology Laboratory, Research Center for Biology, Indonesian Institute of Sciences, Bogor. Furthermore, data collection from Minahasa was made possible with the help of Kres Sondakh and Jelly Sondakh.

\section{REFERENCES}

Alroy J. 2017. Effects of habitat disturbance on tropical forest biodiversity. Proc Natl Acad Sci USA 114 (23): 6056-6061. DOI: 10.1073/pnas.1611855114.

Bakarr MI, da Fonseca ABG, Mittermeier R, Rylands AB, Painemilla KW. 2001. Hunting and bushmeat utilization in the African rainforest: perspective toward blueprint for conservation action (eds). Washington D.C., Center for Applied Biodiversity Science. Conservation International, Washington, DC. USA.

Bennett EL, Robinson JG. 2000. Hunting of Wildlife in Tropical Forests: Implications for Biodiversity and ForestPeoples. The World Bank. Washington, DC.

Cawthorn DM and Hoffman LC. 2015. The bushmeat and food security nexus: A global account of the contributions, conundrums and ethical collisions. Food Res Intl (Ottawa, OnN) 76: 906-925. DOI: 10.1016/j.foodres.2015.03.025

Cowlishaw G, Dunbar R. 2000. Primate Conservation Biology. The University of Chicago Press, Chicago.

Crooks KR, Burdett CL, Theobald DM, King SRB, Di Marco M, Rondinini C, Boitani L. 2017. Quantification of habitat fragmentation reveals extinction risk in terrestrial mammals. Proc Natl Acad Sci. USA 29: 7635-7640. DOI: 10.1073/pnas.1705769114.
Di Marco M, Venter O, Possingham HP, Watson JE. 2018. Changes in human footprint drive changes in species extinction risk. Nat Commun 9: 4621. DOI: 10.1038/s41467-018-07049-5.

Edet SI, Samuel NE, Etim AE, and Titus E. 2014. Impact of overpopulation on the biological diversity conservation in Boki Local Government Area of Cross River State, Nigeria. Amer J Environ Eng 4 (5): 94-98. DOI: 10.5923/j.ajee.20140405.02.

Quirós-Fernández F, Marcos J, Acevedo P., et al. 2017. Hunters serving the ecosystem: the contribution of recreational hunting to wild boar population control. Eur J Wildl Res 63: 57. DOI: 10.1007/s10344017-1107-4.

Fulton EA, Smith ADM, Smith DC. 2011. Human behaviour: the key source of uncertainty in fisheries management. Fish Fisheries 12 (1): 2-17. DOI: 10.1111/j.1467-2979.2010.00371.x.

Garshelis DL, Noyce KV, St-Louis V. 2020. Population reduction by hunting helps control human-wildlife conflicts for a species that is a conservation success story. PLoS ONE 15 (8): e0237274. DOI: 10.1371/journal.pone.0237274.

Gosselin J, Zedrosser A, Swenson JE, and Pelletier F. 2015. The relative importance of direct and indirect effects of hunting mortality on the population dynamics of brown bears. Biol Sci 282 (1798): 20141840. DOI: 10.1098/rspb.2014.1840.

Gray TNE, Hughes AC, Laurance WF, Long B, Lynam AJ, O'Kelly H, Ripple WJ, Seng T, Scotson L, Wilkinson NM. 2018. The wildlife snaring crisis: an insidious and pervasive threat to biodiversity in Southeast Asia. Biodivers Conserv 27: 1031-1037. DOI: 10.1007/s10531-017-1450-5.

Haddad NM, Brudvig LA, Clobert J, Davies KF, Gonzalez A, Holt RD, Lovejoy TE, Sexton JO, Austin MP, Collins CD, Cook WM, Damschen EI, Ewers RM, Foster BL, Jenkins CN, King AJ, Laurance WF, Levey DJ, Margules CR, Melbourne BA, Nicholls AO, Orrock JL, Song DX, Townshend JR. 2015. Habitat fragmentation and its lasting impact on Earth's ecosystems. Sci Adv 1 (2): e1500052. DOI: 10.1126/sciadv.1500052.

Harrison RD, Sreekar R, Brodie JF, Brook S, Luskin M, O'Kelly H, Rao M, Scheffers B, Velho N. 2016. Impacts of hunting on tropical forests in Southeast Asia. Conserv Biol 30 (5): 972-981. DOI: 10.1111/cobi.12785.

Herdiansyah H, Soepandji BS, Seda FSSE, Dewi O. 2014. Conflict management of renewable natural resources in the border of Indonesia-Malaysia. Sustainable Environmental Approach, Procedia Environ Sci 20: 444-450. DOI: 10.1016/j.proenv.2014.03.056.

Herzegovina H, Kusrini MD, Masy'ud B. 2019. Community characteristics and perception of traditional medicine made from herpetofauna in Jakarta and Bandung: Karakteristik dan persepsi masyarakat terhadap obat tradisional berbahan herpetofauna di Jakarta dan Bandung. Media Konservasi 24 (3): 293-302. DOI: 10.29244/medkon.24.3.293-302. [Indonesian]

Ikhsan M, Priyambodo S, Nurmansyah A, Hendarjanti H, Sahari B. 2020. Species diversity, abundance and damaged caused by rats in oil palm plantation in West and Central Sulawesi, Indonesia. Biodiversitas 12 (12): 5632-5639. DOI: 10.13057/biodiv/d211208.

Laatung S. 2019. The hunting of white-tailed rat by Minahasan tribe, North Sulawesi, Indonesia. IOP Conf Ser Earth Environ Sci 399 012032. DOI: 10.1088/1755-1315/399/1/012032.

Latinne A, Suryo S, Kalengkongan J et al. 2020. Characterizing and quantifying the wildlife trade network in Sulawesi, Indonesia. Glob Ecol Conserv 21: e00887. DOI: 10.1016/j.gecco.2019.e00887.

Lone K, Loe LE, Meisingset EL, Stamnes I, Mysterud A. 2015. An adaptive behavioural response to hunting: surviving male red deer shift habitat at the onset of the hunting season. Anim Behav 102: 127138. DOI: 10.1016/j.anbehav.2015.01.012.

Mirdat I, Kartikawati SM, Siahaan S. 2019. Jenis satwa liar yang diperdagangkan sebagai bahan pangan di kota pontianak (The Trade of Wild Animals as Livestock at Pontianak). Jurnal Hutan Lestari 7 (1) : 287 - 295. DOI: 10.26418/jhl.v7i1.31792. [Indonesian]

Musser GG and Carleton MD. 2005. Superfamily Muroidea. In: Wilson DE, Reeder DA (eds.). Mammal Species of the World: a Geographic and Taxonomic Reference. The John Hopkins University Press, Baltimore, USA.

Musser GG. 2014. A systematic review of Sulawesi Bunomys (Muridae, Murinae) with the description of two new species. Bull Amer Mus Natur Hist 863 (1): 1-313. DOI: 10.5531/sd.sp.7. 
University Press, Baltimore, USA.Nasi R, Taber A, van Vliet N. 2011. Empty forests, empty stomachs? bushmeat and livelihoods in the Congo and Amazon Basins. Intl For Rev 13 (3): 355-368. DOI: 10.1505/146554811798293872.

Novriyanti, Masy'ud B and Bismark M. 2014. Pola dan nilai lokal etnis dalam pemanfaatan satwa pada orang rimba bukit duabelas provinsi Jambi (System and ethnic local values in wildlife utilization of Rimba Tribe of Bukit Duabelas Jambi Province). Jurnal Penelitian Hutan dan Konservasi Alam $11 \quad$ (3): 299-313. DOI 10.20886/jphka.2014.11.3.299-313. [Indonesian]

Nukraheni Y, Afriansyah B, Ihsan M. 2019. Ethnozoologi masyarakat suku jerieng dalam memanfaatkan hewan sebagai obat tradisiona yang halal. (The ethnozoology of jering ethnic society in utilizing the animals for halal traditional medicine). J Halal Prod Res 2 (2): 60- 67 DOI: 10.20473/jhpr.vol.2-issue.2.60-67. [Indonesian]

Pattiselanno F and Mentansan G. 2010. Kearifan tradisional suku maybrat dalam perburuan satwa sebagai penunjang pelestarian satwa. (Maybrat tribe traditional wisdom in hunting animals as supporting animal conservation). Makara Seri Sosial Humaniora 14(2), 75-82. DOI: 10.7454/mssh.v14i2.664. [Indonesian]

Pattiselanno F, Manusawai J, Arobaya A, Manusawai H. 2015. Pengelolaan dan konservasi satwa berbasis kearifan tradisional di papua (Wildlife Management and Conservation Based on Traditional Wisdom in Papua). Jurnal Manusia dan Lingkungan, 22 (1), 106-112. DOI: $10.22146 / j m l .18731$. [Indonesian]
Ripple WJ, Abernethy K, Betts MG, et al. 2016. Bushmeat hunting and extinction risk to the world's mammals. R Soc Open Sci 3: 160498. DOI: $10.1098 /$ rsos. 160498

Tilker A, Nguyen A, Abrams JF, Bhagwat T, Le M, Van Nguyen T, Wilting A et al. 2020. A little-known endemic caught in the Southeast Asian extinction crisis: The Annamite striped rabbit Nesolagus timminsi. Oryx 54(2) : 178-187. DOI: 10.1017/S0030605318000534.

Tipawan T, Jarun T. 2016. The efficiency of material types of box fences to prevent rat damage in oil palm plantations. Intl J Agric Technol 12 (7.1): 1491-1498.

Vannevel R, Goethals PLM. 2020. Identifying ecosystem key factors to support sustainable water management. Sustainability 12 (3): 1148. DOI: $10.3390 / \mathrm{su} 12031148$.

Verma M, Symes WS, Watson JEM, Jones KR, Allan JR, Venter O, Rheindt FE, Edwards DP, Carrasco LR. 2020. Severe human pressures in the Sundaland biodiversity hotspot. Conserv Sci Pract 2 (3): e169. DOI: $10.1111 / \mathrm{csp} 2.169$.

Wiafe ED. 2018. Hunted species and hunting equipment used by rainforest poachers in Ghana. J Threatened Taxa 10 (2): 1128511289. DOI: $10.11609 /$ jott.3416.10.2.11285-11289.

Wu J. 2013. Key concepts and research topics in landscape ecology revisited: 30 years after the Allerton Park workshop. Landscape Ecol 28: 1-11. DOI: 10.1007/s10980-012-9836-y.

Wyatt T, Johnson K, Hunter L, et al. 2018. Corruption and wildlife trafficking: three case studies involving Asia. Asian Criminol 13, 3555. DOI: $10.1007 / \mathrm{s} 11417-017-9255-8$ 